\title{
Remittances and the Household's Expenditures on Health
}

\author{
Jorge N. Valero-Gil \\ Universidad Autónoma de Nuevo Leon • Monterrey, Mexico
}

\section{Abstract}

This paper considers the effect of remittances on the share of health expenditures in total household expenditure in Mexico. The main purpose of this paper is to investigate if remittances are especially targeted towards household's health expenditure in Mexico. Using IV Tobit and regression models we find a statistically significant effect of remittances on the household health expenditures shares. This effect is even more pronounced for households without access to the employment's medical insurance.

\section{Introduction}

This paper analyzes the impact of remittance transfers on health expenditure of Mexican households. Using data from the National Income Expenditure Survey of Households of Mexico (ENIGH) for the year 2004, this paper examines if remittances are intended to spend on healthcare for the migrant-sending families in Mexico. The basic idea is to test the fungibility hypothesis that posits that a dollar is a dollar and the household will expend it on the good with the highest marginal utility, irrespective of its origin. This will be done by making a distinction between the marginal impact of an increase in income and that of targeted remittances and by presenting their respective estimates. The results are expected to have potential public policy implications for remittances. Note that health expenditure is an attractive area to study the impact of remittances. According to the data generated by the Mexican Migration Project for the period 2005-2007, while 43.3 percent of people covered in the study reported that the most important motive for sending remittances is food and sustenance, other 35.8 percent considered health expenditure to be the most important reason. Amuedo-Dorantes et al. (2007) report that 46 percent of the people remitting money consider household's health expenditures (HHE) to be the most important motive for sending remittances.

According to the World Health Organization (2007a), national expenditure on health in Mexico was 6.5 percent of GDP: government expenditures account for 3.0 percent and private expenditures account for 3.5 percent. Furthermore, the proportion of remittances in national income has been increasing in Mexico over the years: 
from 3,673 million U.S. dollars (USD) in 1994 to 16,613 million in 2004, according to Banco de Mexico (BANXICO, 2005). Table 1 presents data on HHE, out-ofpocket expenditure, and remittances for the countries of the Central America Free Trade Agreement (CAFTA) and Mexico. Total expenditure on health as a percentage of GDP cannot be explained by general government expenditure or by remittances alone. Out-of-pocket expenditure on health seems to be directly related to remittances but this relationship is not the same for each country.

\section{Table 1}

\section{Health Expenditure and Remittances for Selected Countries}

\begin{tabular}{|c|c|c|c|c|}
\hline $\begin{array}{l}\text { Total } \\
\text { expenditure } \\
\text { on health as } \\
\% \text { of gross } \\
\text { domestic } \\
\text { product } \\
(2003) \\
(1)\end{array}$ & $\begin{array}{c}\text { General } \\
\text { government } \\
\text { expenditure } \\
\text { on health as } \\
\% \text { of total } \\
\text { expenditure } \\
\text { on health } \\
\text { (2003) } \\
(2)\end{array}$ & $\begin{array}{l}\text { Out-of-pocket } \\
\text { expenditure } \\
\text { as \% } \\
\text { of private } \\
\text { expenditure } \\
\text { on health } \\
\text { (2003) } \\
\text { (3) }\end{array}$ & $\begin{array}{l}\text { Out-ol-pocket } \\
\text { expenditure } \\
\text { as \% of gross } \\
\text { domestic } \\
\text { product } \\
\text { (2003) } \\
\text { (4) }\end{array}$ & $\begin{array}{l}\text { Remitances } \\
\text { as \% of gross } \\
\text { domestic } \\
\text { product } \\
\text { (2005) } \\
\text { (5) }\end{array}$ \\
\hline 7.3 & 78.8 & 88.7 & 1.4 & 1.8 \\
\hline 7.0 & 33.2 & 70.8 & 3.3 & 9.1 \\
\hline 8.1 & 46.1 & 93.5 & 4.1 & 17.1 \\
\hline 5.4 & 60.3 & 91.9 & 3.0 & 9.3 \\
\hline 7.1 & 56.5 & 85.8 & 2.6 & 21.2 \\
\hline 6.2 & 46.4 & 94.2 & 3.7 & 2.8 \\
\hline 7.7 & 48.4 & 95.7 & 3.8 & 16.9 \\
\hline
\end{tabular}

Columns (1) to (4) are from The World Health Organization (2007b, Table 2, p. 180). Column (5) is from The Inter-American Development Bank (2005).

Most research on the relationship between remittances and health that utilizes household data finds a strong link between them. Some research focuses on the relationship between remittances and health outcomes. For example, Acosta et al. (2007) find that children from households that report receiving remittances tend to exhibit higher health outcomes than those from non-recipients in the cases of Guatemala and Nicaragua; López-Córdoba (2006) finds that an increase in remittances lowers infant mortality rates in Mexico at the municipal level. Other studies the relationship between migration and health. For example, Hildebrand and McKenzie (2005) study the channels through which migration may affect health outcomes and find evidence 
that migration improves children's health through raising the health knowledge of mothers, in addition to the direct effect on health of higher wealth after migration. Rubalcava et al. (2008) find little evidence in support of the hypothesis that migrants are positively selected in terms of health.

The current research is about the relationship between remittances and HHE. Cardona and Medina (2005) study this relationship in Colombia using, as in this paper, the proportion of health expenditure as the dependent variable but do not find any significant effect of remittances on health expenditures. Amuedo-Dorantes et al. (2007) use HHE as dependent variable and find a positive relationship with remittances in Mexico. Both studies use ordinary least squares (OLS) and instrumental variable (IV) methods. Using a two-tiered Tobit model, Amuedo-Dorantes and Pozo (2008) further find a positive relationship between HHE and remittances. Our strategy is to use the $2004 \mathrm{ENIGH}$ sample data to estimate Tobit and regression models, that control for the household's expenditure per capita, which allows us to separate "income" and "remittance" effects. Note that we use per capita expenditure over per capita income. It has been argued that expenditure is measured better than income and, therefore, it is more reliable. ${ }^{1}$ The choice of HHE share in total household expenditure (not HHE per se) as the dependent variable in our empirical analysis is dictated by the fact that it allows us to relate our model to a cost function as will be discussed later. Further, the heterocedasticity problem that arises when HHE is used (because high income people tend to have higher HHE variances compared to low income people) can be avoided. The Tobit model also allows us to distinguish between private and social effects of remittances. We examine the differential impacts based on whether households have access to the Employment's Medical Insurance (EMI) or not. In addition, we look for the ultimate sampling unit (Cameron \& Trive$\mathrm{di}, 2005$ ) in order to control for unobserved heterogeneity such as prices, distance to the health center, and other community specific factors. McKenzie (2007), and McKenzie and Sasin (2007) emphasize the importance of using a migration variable to study a particular household outcome, such as health expenses, because of the difficulty of disentangling the effects of migration and remittances. ${ }^{2}$ To separate these effects we use a proxy variable for migration. We address the endogeneity issue by introducing instruments that are consistent with the existing literature.

We contribute to the literature on HHE and remittances in several ways. We measure the income (expenditure) effect and remittance effect on health expenditure separately. Another major contribution is the measurement of the effects of remittances on household health expenditures for households with and without access to employment medical insurance. The control for migration in the model that ad- 
dresses an important heterogeneity issue is an additional contribution of this article. The discussion on private and social measurement of the effects of remittances on health expenditure is also new to the existing literature.

\section{The Data}

Our source of data is the National Income Expenditure Survey of Households of Mexico (ENIGH) for the year 2004. The households' expenditure in the ENIGH is composed of two parts: a monetary and a non-monetary component. The non-monetary component refers to expenses that are not an out-of-pocket expenditure, but are estimated expenditures on household production, gifts, labor payments in kind, and non-monetary support from institutions. We do not include the non-monetary component because the interest of this study lies in the relationship between remittances (a monetary transfer) and health expenditures.

The labor market in Mexico is divided into two parts: a formal sector that complies with the law and has access to EMI, and an informal sector. In the formal sector, the government workers and their children have access to EMI through the Instituto de Seguridad y Servicios Sociales de los Trabajadores del Estado (ISSSTE), the private industry workers through the Instituto Mexicano del Seguro Social (IMSS), and some other workers through their firms' medical services. ${ }^{3}$ We infer this labor market division by considering whether a household does or doesn't have access to the medical services provided by the formal sector, i.e., to EMI. In general, the workers without access to EMI are in the informal sector or in the agricultural sector and their labor income is unreported to tax authorities. We consider a household as having access to EMI if the head of the family or the spouse has access to at least one of the above mentioned medical insurance institutions. The ENIGH sample has 22,595 households and $31.6 \%$ of these households have access to EMl if we consider the head's access only, and $35.4 \%$ if we consider the head and/or the spouse. An alternative we use is to take the households with at least one household member having access to EMI (45.2\%). But it is a weaker measure as the EMI access of the son or daughter cannot usually be extended to their parents, brothers, and sisters. However, the empirical results with this alternative measure are qualitatively similar showing their robustness.

There are three issues to consider while using data on remittances in Mexico. First, there are differences in the amount of remittances between the data provided by Banco de Mexico (BANXICO), the Central Bank of Mexico, and the household data collected by ENIGH. ${ }^{4}$ The total amount of worker remittances, according to 
BANXICO (2008), during the third quarter (July - September) of 2004 is USD 4,551 million and the remittances reported by ENIGH during the period August October 2004 are USD 1,037 million. Second, both data sources show that some of the more industrialized states, such as Distrito Federal, State of Mexico and Jalisco, are among the most important recipients of remittances. It indicates that remittance transfers do not necessarily have anything to do with rural community or with poverty. Finally, the remittance transfers to the households are largely constant over time. As ENIGH reports, transfers for the last six months before the household's interview, we find a correlation coefficient between remittances in the first three months and in the last three months to be 0.996 and the correlation coefficient for transfers from institutions to be 1.0. This shows that transfers, including remittances, are continuous flows and they are not just a response to emergency need for money, as likely to happen with a health probIem in the household.

Table 2

Sample Means and Standard Deviations

\begin{tabular}{lcccccc} 
& \multicolumn{2}{c}{ All } & \multicolumn{2}{c}{ Access to EMI } & \multicolumn{2}{c}{ No access to EMI } \\
& Mean & Std. Dev. & Mean & Std. Dev. & Mean & Std. Dev. \\
\hline W & 0.033 & 0.073 & 0.024 & 0.053 & 0.038 & 0.081 \\
$X$ & 20937 & 27236 & 27906 & 26442 & 17125 & 26909 \\
Inx/n & 8.27 & 0.97 & 8.66 & 0.82 & 8.05 & 0.97 \\
Lnn & 1.27 & 0.55 & 1.30 & 0.46 & 1.25 & 0.59 \\
Rem & 414 & 16128 & 80 & 1351 & 598 & 20032 \\
Insti & 339 & 1412 & 127 & 917 & 456 & 1608 \\
Mig & 3.36 & 3.86 & 2.88 & 2.95 & 3.62 & 4.26 \\
EMi & 0.45 & 0.50 & & & & \\
\hline
\end{tabular}

W: Proportion of expenditure on health: X: expenditure. $\mathrm{n}$ : soze of the household. Rem: remittances. Insti: transfers from institutions. Mig: fraction of migrants.

In Table 2, we present selected summary statistics for the data that will be used in the study. The number of households in the sample is 22,547 from a population of 25 million households. The Table shows the means and standard deviations of the variables separated by whether the household has access to EMI or not. The proportion of monetary expenditures on health is $3.3 \%$, but it is $2.4 \%$ for households with access to EMI and 3.8\% for households without access. Households without access to EMI have a higher proportion of total expenditure devoted to health, a lower 
expenditure per capita, a smaller household size, higher transfers from remittances and from institutions, and are in localities with a higher percentage of migrants.

\section{The Model}

\section{The basic model specification}

In order to study the target effect of remittances on HHE, we require a model that relates the share of expenditures in health ( $w)$ to remittances $(\mathrm{rem})$ and total household's expenditure per capita $(x)$, and that simultaneously controls for access to $E M I$ and for migration (mig). To control for migration, we use as a proxy variable: the percentage of households with family migrants in the United States in last five years, at the municipality level. This information is obtained from Tuirán et al. (2002) and it refers to the year 2000. We also control for the size and composition of the household and other characteristics.

In order to control for differences in prices and unobserved heterogeneity between localities such as distance to the health center and other factors, we use the ultimate sampling unit to form clusters $(c)$. We consider just one price in every locality, but we allow the price to vary among clusters as in Deaton's (1997) model. We require localities to be as small and as distant from each other as possible because each locality has just one price for goods related to health. Besides localities we use sample expansion factors to expand from the sample to the population in order to build as many clusters as possible. ${ }^{5}$ Note that we use these expansion factors just to distinguish one cluster from another. As these clusters come from a sample and we want to extend the results to the population, we use a random effects model and consider the clusters to be randomly distributed in the sample.

We specify the model as an Engel function which relates the fraction of total household expenditures devoted to health with total household expenditure per capita, as in Working (1943). This model, discussed by Deaton (1989), has been widely used (e.g. Gibson \& Rozelle, 2004; Hong \& Kim, 2000) and variants can be found in Atkinson, Gomulka and Stern (1990), and Valero-Gil (2006) for Mexico. The model is as follows: ${ }^{6}$

$$
\begin{gathered}
w_{c h}=\frac{p q_{h}}{x_{h}}=\beta_{0}+\beta_{1} \ln (x / n)_{c h}+\beta_{2}\left[\ln (x / n)_{c h}\right]^{2}+\beta_{3} \ln n_{c h}+ \\
\eta_{1} r e m_{c h}+\eta_{2} \operatorname{rem}_{c h}{ }^{2}+\eta_{3} E M I_{c h}+\eta_{4} E M I_{c h} * \ln (x / n)_{c h}+ \\
\eta_{5} E M I_{c h} * \operatorname{rem}_{c h}+\eta_{6} m i g_{c h}+\sum_{j=1}^{s} \gamma_{j}\left(\frac{n_{c j h}}{n_{c h}}\right)+\delta \cdot z_{c h}+u_{c}+\varepsilon_{h}
\end{gathered}
$$


The left hand side of the equation is the fraction of total expenditure $x$ on health $p q_{h}$, where $p$ are prices and $q_{h}$ quantities of "health goods" consumed by the household $h$. The subscripts $c$ and $h$ indicate cluster and household respectively. The expenditure on health, $p q_{h}$, is observed but not $p$ and $q_{h}$ separately, $\ln (x / n)_{h}$ is the natural logarithm of the expenditure per capita of household $h, n_{h}$ is the size of the household, remittances are denoted by rem which are censored at zero in $95.6 \%$ of the cases and cannot be included in logarithm. The proxy for a migrant in the household is denoted by mig and access to EMI by EMI. We also interact EMI with total expenditures per capita and with remittances. Different prices and heterogeneity in each cluster are indicated by ${u_{c}}{ }^{7}$ The stochastic error $\varepsilon$ has zero mean, constante variance, and is assumed to be independently and identically distributed among households.

In order to control for the age and sex of the members of the household, we define ten groups, one for people $0-6$ years of age and one for 66 years and above, and four more groups for each sex according to the age groups $7-15,16-24,25-$ 54 and $55-65$. With these groups we define the composition of the family as $n / n$, where $j$ represents each of the ten groups, $n_{j}$ the number of people in group $j$ and $n / n$ the proportion of people in group $j$. We also utilize a vector of control variables $z_{c h}$, that includes sex and marital status of the head of the household, four different geographic regions, and four different sizes of the localities.

Our null hypothesis is that $\eta_{1}, \eta_{2}$ and $\eta_{5}$ are equal to 0 , implying that remittances do not have any effect on the HHE share. In order to compare the effect of remittances on HHE with the effect of other transfers, we run a similar regression using transfers from institutions (insti) instead of remittances. This is important because it considers whether any extra income from transfers could have the same effect on HHE as do remittances. In particular, the specification allows us to test whether households expend a dollar on the good with the highest marginal utility per dollar, independently of whether the dollar comes from remittances, institutional transfers, or other sources.

\section{Endogeneity}

There is a well known concern about the endogeneity problem in the literature: the possibility that an increase in HHE increases remittances even though, as we have discussed in the last section, that remittances behave as a continuous flow. To correct this problem we can use instrumental variables, which should be related to remittances but unrelated to the error term. These variables will also correct the 
measurement error problem in remittances discussed in the last section. One way to consider this is to think of a variable related to remittances but unrelated to HHE. Based on the Population Census of 2000, Tuirán et al. (2002) present information about the percentage of return migration between 1995-2000, at the municipal level. We use this variable as an instrument because although health expenditures could be a cause of migration and of remittances, they being a cause of return migration is much weaker. We calculate the percentage of return migration and obtain its median. Then we introduce a dummy variable that takes the value of 1 if the percentage is greater than the median and the value of 0 otherwise. We calculate the Spearman's rank correlation coefficient and find that the correlation between the return migration dummy and remittances is significantly different from zero at a level lower than 0.001 percent, But the correlation between the return migration and the health expenditures share is much weaker. We further consider the distance between the locality where the household resides and the border with the United States as an alternative instrument. ${ }^{8}$ But its correlation either with rem or with $w$ is found to be statistically insignificant. The distance to the border variable has been used by López-Córdoba (2006) and Amuedo-Dorantes and Pozo (2008) but has been criticized by McKenzie and Sasin (2007).

To estimate equation (1) we use two instrumental variable (IV) procedures: a two-stage predictor substitution model (2SPS) and a two-stage residual inclusion model (2SRI). In both cases the first stage involves an estimation of remittances using both the exogenous and the instrumental variables. In the second stage, we substitute the estimated remittances in equation (1) in the case of 2SPS, and we include the error of the first stage as an additional variable in the case of 2SRI. Terza et al. (2008), following the work of Hausman (1978), Smith and Blundell (1986), and others, show that the use of 2SRI generates better results than 2SPS in the estimation of nonlinear models with endogenous regressors.

\section{Tobit model and marginal values.}

The proportion of health expenditure is censored at zero for $35 \%$ of the households and for this reason we follow a Tobit model specified as follows:

$$
\begin{aligned}
& w_{c h}^{*}=\boldsymbol{\beta} \boldsymbol{X}_{c h}+\varepsilon_{c h} \\
& w_{c h}=0 \text { if } w_{c h}^{*} \leq 0 \text { and } w_{c h}=w_{c h}^{*} \text { if } w_{c h}^{*}>0
\end{aligned}
$$


In this model $w_{c h}$ is the observed variable and wch* is the threshold variable. This model generates two marginal values $\partial w / \partial \boldsymbol{X}$, one for $\mathrm{E}\left[w_{c h}{ }^{*} \mid \boldsymbol{X}_{c h}\right]$ and the other for $\mathrm{E}\left[w_{c h} \mid \boldsymbol{X}_{c h}\right]$ which equals $\mathrm{E}\left[w_{c h}{ }^{*} \mid \boldsymbol{X}_{c h}, w_{c h}{ }^{*}>0\right]$. Intuition suggests that we should consider $\mathrm{E}\left[w_{c h} \mid \boldsymbol{X}_{c h}\right]$ since we never observe health expenditures lower than zero. We could consider the values for $w_{c h}{ }^{*}<0$ if we want to evaluate health expenditure as a social problem. For example, we can think that the poor will not expend any part of an extra peso on health. This would be the case of people in poverty or of people wanting to sell their health in order to obtain other goods. ${ }^{9}$ The relationship between poverty and the probability of incurring health expenditures is well documented, as in Wagstaff (2002), Ochoa-Díaz et al. (1999), and Suárez-Berenguela (2000). However, if we want to evaluate health expenditure as a private problem, such as in the case of the private sales of a medical service or product, it could be more relevant to use $\mathrm{E}\left[w_{c h} \boldsymbol{X}_{c h}\right]$. Even in the sales scenario, Debb and Trivedi (2002) have shown that for the case of count data on health expenditures, a threshold model using $w^{*}$ is preferred to a two-step model that separates the cases between $w_{c h}=0$ and $\mathrm{w}_{\mathrm{ch}}>0$. The relationship between both marginal values generated by $\mathrm{E}\left[w_{c h} \mid \boldsymbol{X}_{c h}\right]$ and $\mathrm{E}\left[w_{c h}{ }^{*} \mid \boldsymbol{X}_{c h}\right]$ is given by $\boldsymbol{\beta}^{\prime} \phi\left(X^{\prime} \boldsymbol{\beta} / \sigma_{\varepsilon}\right)$ where $X^{\prime} \boldsymbol{\beta}$ are the estimated values and $\phi$ refers to the standard normal distribution. Following the literature, we will refer to the total values generated by $\mathrm{E}\left[w_{c h}{ }^{*} \boldsymbol{X}_{c h}\right]$ and marginal values generated by $\mathrm{E}\left[w_{c h} \mid \boldsymbol{X}_{c h}\right]$ as social and privates values respectively. ${ }^{10}$

\section{$\overline{\text { Results }}$}

In Table 3, we present results from the following estimation methods: the Tobit model without using instrumental variables for remittances, the Tobit model with instrumental variables for remittances using the 2SPS procedure, the Tobit model with instrumental variables for remittances using the 2SRI procedure, and two GLS models, one for $w>0$ and one for $w \geq 0$, for comparison purposes. In every case we use random effects to control for heterogeneity by locality, but the use of these effects do not alter the results in a significant way, perhaps because we are using a full set of variables.

Columns (1) to (5) present the results for the Tobit models while columns (6) and (7) present the results for the GLS models. Column (1) refers to the Tobit model without instrumental variables and shows that there is a positive effect of remittances on a household's health expenditure: higher remittances to the household are accompanied by a larger share of expenditure on health. The coefficients for expenditures per capita, remittances, and EMI are all significantly different from zero. 
Heterogeneity related to migration increases the share of household's health expenditures (HHE): households with migrants could have a higher propensity to expend in healthcare. In the second part of the table the marginal values are presented. As discussed above, they refer to the case $\mathrm{E}\left[w_{c h}{ }^{*} \mid \boldsymbol{X}_{c h}, w_{c h}{ }^{*}>0\right]$. The marginal values are lower when compared to the total values. If we use transfers from institutions (inst) in place of remittances, shown in column (2), we find that this type of transfers do not significantly affect HHE. Therefore, our findings indicate that remittances are "earmarked" and that the relationship between remittances and HHE cannot be extended to other types of transfers. All of the results in Table 3 show that remittances have a positive impact on the fraction of health expenditures by the household, but as expected, this effect is significantly smaller for households with employment's medical insurance. In column (3) we re-run the same regression as in column (1) using an alternative definition of households with/without medical insurance as a robustness check. In this specification, we define a household as having access to employment's medical insurance if at least one member of the household has access to EMI. Our results are robust to this alternative definition of household access to EMI.

As discussed above, to deal with the endogeneity problem, we estimate the model with the percentage of return migration as an instrument.. The results of the IV Tobit model are presented in column (4) for the 2SPS procedure and in column (5) for the 2SRI procedure. The estimated coefficients of remittances from the 2SPS procedure reported in column (5) are smaller in magnitude than those in column (4) and the coefficient for $\mathrm{rem}^{2}$ changes sign. However, the 2SRI generates coefficients similar to those of column (1). "As discussed above, according to Terza, Basu and Rathouz (2008), the 2SRI procedure is consistent and produces better results than the 2SPS procedure in non-linear case like ours. ${ }^{12}$

In the last two columns, the GLS regression results are presented: for the case $w>0$ in column (6) and for the case $w \geq 0$ in column (7). The results for $w>0$ are comparable to the marginal effect results because they apply to the households with $w>0$. The results for $w \geq 0$ measure the quantity demanded for health including actual consumers and non-consumers, as suggested by Deaton (1997), as an additional result for comparison purposes.

To test if the partial derivatives evaluated at the means $\partial w / \partial \mathrm{rem}$ and $\partial w / \partial \ln (x / n)$, are significantly different from zero, we use the information of equation (1) and the mean values of rem and $\ln x / \mathrm{n}$ of Table $2 .{ }^{13}$ Table 4 presents the effects on the means using the estimates of the IV Tobit and GLS models shown in column (4) to (7) of Table 3. The results from $F$-test for significance of differences between the mean 
Table 3

Effects of variables in the share of health expenditure

\begin{tabular}{|c|c|c|c|c|c|c|c|}
\hline & $(t)$ & (2) & (3) & (4) & (5) & (6) & (7) \\
\hline & TOBIT & $\begin{array}{c}\text { TOBIT } \\
\text { Insti' }\end{array}$ & $\begin{array}{l}\text { TOBIT } \\
\text { EMI }{ }^{2}\end{array}$ & $\begin{array}{c}\text { IV TOBIT } \\
\left.2 S R\right|^{3}\end{array}$ & $\begin{array}{l}\text { TOBIT } \\
2 \text { SPS }^{4}\end{array}$ & $\begin{array}{l}\text { GLS }^{5} \\
w>0\end{array}$ & $\begin{array}{c}\text { GLS } \\
w \geq 0\end{array}$ \\
\hline & & Insti1 & EMI2 & $2 S R l^{3}$ & $2 S P S^{4}$ & $w>0$ & $G L S W \geq 0$ \\
\hline Constant & $\begin{array}{c}-0.426 \\
(-11.58)\end{array}$ & $\begin{array}{c}-0.417 \\
(-11.45)\end{array}$ & $\begin{array}{c}-0.439 \\
(-12.28)\end{array}$ & $\begin{array}{c}-0.422 \\
(-11.72)\end{array}$ & $\begin{array}{c}-0.382 \\
(-10.53)\end{array}$ & $\begin{array}{l}0.157 \\
(3.95)\end{array}$ & $\begin{array}{l}-0.052 \\
(-2.27)\end{array}$ \\
\hline $\ln x / n$ & $\begin{array}{l}0.084 \\
(9.53)\end{array}$ & $\begin{array}{l}0.081 \\
(9.25)\end{array}$ & $\begin{array}{c}0.087 \\
(10.15)\end{array}$ & $\begin{array}{l}0.082 \\
(9.01)\end{array}$ & $\begin{array}{l}0.080 \\
(8.61)\end{array}$ & $\begin{array}{l}-0.016 \\
(-1.71)\end{array}$ & $\begin{array}{l}0.015 \\
(2.78)\end{array}$ \\
\hline$(\ln x / n)^{2}$ & $\begin{array}{l}-0.003 \\
(-6.53)\end{array}$ & $\begin{array}{l}-0.003 \\
(-6.02)\end{array}$ & $\begin{array}{l}-0.004 \\
(-7.03)\end{array}$ & $\begin{array}{l}-0.003 \\
(-5.64)\end{array}$ & $\begin{array}{l}-0.003 \\
(-5.22)\end{array}$ & $\begin{array}{l}0.001 \\
(2.46)\end{array}$ & $\begin{array}{c}0.000 \\
(-0.47)\end{array}$ \\
\hline Rem & $\begin{array}{c}1.45 \mathrm{E}-06 \\
(4.61)\end{array}$ & $\begin{array}{c}-6.40 E-07 \\
(-0.76)\end{array}$ & $\begin{array}{c}1.53 \mathrm{E}-06 \\
(4.65)\end{array}$ & $\begin{array}{c}1.49 \mathrm{E}-06 \\
(4.57)\end{array}$ & $\begin{array}{c}2.64 \mathrm{E}-07 \\
(1.78)\end{array}$ & $\begin{array}{c}1.25 E-06 \\
(4.21)\end{array}$ & $\begin{array}{c}1.32 E-06 \\
(5.73)\end{array}$ \\
\hline rem² & $\begin{array}{c}-4.88 \mathrm{E}-13 \\
(-3.7)\end{array}$ & $\begin{array}{c}5.25 e-13 \\
(0.03)\end{array}$ & $\begin{array}{c}-5.20 \mathrm{E}-13 \\
(-3.77)\end{array}$ & $\begin{array}{c}-5.20 \mathrm{E}-13 \\
(-3.95)\end{array}$ & $\begin{array}{c}6.75 \mathrm{E}-13 \\
(2.08)\end{array}$ & $\begin{array}{c}-4.23 \mathrm{E}-13 \\
(-3.41)\end{array}$ & $\begin{array}{c}-4.44 \mathrm{E}-13 \\
(-4.58)\end{array}$ \\
\hline EMI & $\begin{array}{l}-0.065 \\
(-4.04)\end{array}$ & $\begin{array}{l}-0.047 \\
(-3.18)\end{array}$ & $\begin{array}{l}-0.060 \\
(-4.02)\end{array}$ & $\begin{array}{c}-0.068 \\
(-4.3)\end{array}$ & $\begin{array}{l}-0.076 \\
(-4.06)\end{array}$ & $\begin{array}{l}-0.018 \\
(-1.09)\end{array}$ & $\begin{array}{l}-0.011 \\
(-0.96)\end{array}$ \\
\hline $\ln x / n^{\star} E M \mid$ & $\begin{array}{c}4.93 \mathrm{E}-03 \\
(2.66)\end{array}$ & $\begin{array}{c}2.65 \mathrm{E}-03 \\
(1.51)\end{array}$ & $\begin{array}{c}4.13 \mathrm{E}-03 \\
(2.38)\end{array}$ & $\begin{array}{l}0.005 \\
(2.73)\end{array}$ & $\begin{array}{c}4.93 \mathrm{E}-03 \\
(2.35)\end{array}$ & $\begin{array}{c}5.77 \mathrm{E}-04 \\
(0.31)\end{array}$ & $\begin{array}{c}-2.57 E-04 \\
(-0.2)\end{array}$ \\
\hline $\mathrm{rem}^{\star} \mathrm{EMI}$ & $\begin{array}{c}-1.55 \mathrm{E}-06 \\
(-1.8)\end{array}$ & $\begin{array}{c}2.80 \mathrm{e}-07 \\
(0.21)\end{array}$ & $\begin{array}{c}-1.10 \mathrm{E}-06 \\
(-1.56)\end{array}$ & $\begin{array}{c}-1.60 E-06 \\
(-1.85)\end{array}$ & $\begin{array}{c}-5.77 \mathrm{E}-08 \\
(-1.16)\end{array}$ & $\begin{array}{c}-1.40 \mathrm{E}-06 \\
(-1.77)\end{array}$ & $\begin{array}{c}-1.46 \mathrm{E}-06 \\
(-2.31)\end{array}$ \\
\hline Mig & $\begin{array}{c}1.60 \mathrm{E}-03 \\
(6.62)\end{array}$ & $\begin{array}{c}1.67 \mathrm{E}-03 \\
(6.94)\end{array}$ & $\begin{array}{c}1.55 \mathrm{E}-03 \\
(7.59)\end{array}$ & $\begin{array}{c}1.74 \mathrm{E}-03 \\
(3.73)\end{array}$ & $\begin{array}{c}1.31 \mathrm{E}-03 \\
(2.61)\end{array}$ & $\begin{array}{c}7.46 \mathrm{E}-04 \\
(3.68)\end{array}$ & $\begin{array}{c}9.40 E-04 \\
(6.44)\end{array}$ \\
\hline
\end{tabular}


Table 3 cont'd

Effects of variables in the share of health expenditure

(1)

(2)

(3)

(4)

(5)

(6)

(7)

\section{Marginal values}

\begin{tabular}{|c|c|c|c|c|c|c|c|}
\hline $\ln x / n$ & 0.032 & & & 0.031 & 0.030 & & \\
\hline$(\ln x / n)^{2}$ & -0.001 & & & -0.001 & -0.001 & & \\
\hline Rem & $5.47 E-07$ & & & $5.63 E-07$ & $9.94 \mathrm{E}-08$ & & \\
\hline rem ${ }^{2}$ & $-1.84 E-13$ & & & $-1.96 \mathrm{E}-13$ & $2.55 E-13$ & & \\
\hline EMI & -0.023 & & & -0.024 & -0.027 & & \\
\hline $\ln x / \mathrm{n}^{\star} \mathrm{EMI}$ & 0.002 & & & 0.002 & 0.002 & & \\
\hline $\mathrm{rem}^{\star} \mathrm{EMI}$ & $-5.85 E-07$ & & & $-6.03 E-07$ & $-2.18 \mathrm{E}-08$ & & \\
\hline Mig & $6.04 \mathrm{E}-04$ & & & $6.55 E-04$ & $4.96 \mathrm{E}-04$ & & \\
\hline Log likehood & 8507 & 8078 & 9437 & 8689 & 8980 & & \\
\hline R-sq: within & & & & & & 0.060 & 0.047 \\
\hline Between & & & & & & 0.112 & 0.112 \\
\hline Overall & & & & & & 0.078 & 0.062 \\
\hline sigma $s_{e}$ & 0.094 & 0.092 & 0.093 & 0.093 & 0.094 & .0821 & .070 \\
\hline
\end{tabular}

Notes: t-statistics in parentheses: Number of observations; 21139 , censored: 7440 , uncensored 13,694; number of groups 3,074. Other control variables used are sex and marital status of the head of the family, 9 variables for composition of sex and age of the members of the household, 3 for geographic zone and 3 for size of the locality. ${ }^{1}$ In column (2) the variable remi was substituted by the variable insti (transfers from institutions). ${ }^{2}$ In column (3) the variable EMI was changed considering access to EMI if at least one member has access to EMl. ${ }^{3}$ IV refers to instrumental variables and $2 S R I$ to the method of two-stage residual inclusion. ${ }^{4}$ 2SPS refers to two-stage predictor substitution. ${ }^{5}$ GLS, generalized least squares, refers in this case to the technique of ordinary least squares plus random effects. 
coefficients of remittances with/without EMI groups are also presented. The results show a positive sign for the effect on the mean for remittances if the household does not have access to EMI and in most cases a negative sign if the household has access. This reinforces the conclusion that remittances have a target effect of increasing the proportion of health expenditures for households without access to EMI.

\section{Table 4}

\section{Effects on the means}

\begin{tabular}{|c|c|c|c|c|}
\hline \multirow[t]{2}{*}{ Methods } & \multicolumn{2}{|c|}{ Effects on the means } & \multicolumn{2}{|c|}{ Prob > F } \\
\hline & Rem & Expenditure & Rem & Expenditure \\
\hline \multicolumn{5}{|l|}{ IV TOBIT 2SRI } \\
\hline Access to EMI & $-1.10 E-07$ & 0.030 & $0.90^{\star \star}$ & $0.00^{\star \star \star}$ \\
\hline No access to EMI & $1.49 E-06$ & 0.029 & $0.00^{\star \star}$ & $0.00^{\star \star \star}$ \\
\hline \multicolumn{5}{|l|}{ IV TOBIT 2SLS } \\
\hline Access to EMI & 2.06E-07 & 0.029 & 0.05 & $0.00^{\star \star \star}$ \\
\hline No access to EMI & 2.65E-07 & 0.028 & 0.00 & $0.00^{\star \star \star}$ \\
\hline \multicolumn{5}{|l|}{ GLS $w>0$} \\
\hline Access to EMI & $-1.50 \mathrm{E}-07$ & 0.008 & $0.83^{\star}$ & 0.07 \\
\hline No access to EMI & $1.25 \mathrm{E}-06$ & 0.006 & $0.00^{*}$ & 0.03 \\
\hline \multicolumn{5}{|l|}{ GLS $w \geq 0$} \\
\hline Access to EM! & $-1.40 E-07$ & 0.012 & $0.82^{\star \star}$ & 0.63 \\
\hline No access to EMI & $1.32 E-06$ & 0.013 & $0.00^{\star \star}$ & 0.64 \\
\hline
\end{tabular}

The coefficients of the effects on the means for the groups with and without access to EMl are significantly different at $1 \%$ level $\left({ }^{\star \star \star}\right), 5 \%$ level $\left({ }^{\star \star}\right), 10 \%$ level $\left({ }^{\star}\right)$.

In Table 5, we present an example to illustrate the use of our results by considering the effects of a $10 \%$ increase in remittances, and the difference between effects of household expenditures and of "earmarked" remittances on HHE. First, the table shows the effects of a $10 \%$ increase in remittances for households with and without EMI, estimated by using the IV Tobit with 2SRI (column 1-2), the IV Tobit with 2SLS (column 3-4) and GLS with $w \geq 0$ and $w>0$ (column 5-6). The first three rows of Table 6 are taken from Table 2: the share of HHE in total expenditures, $w$, health expenditures $w^{*} x$ and remittances rem. Row 4 shows that a $10 \%$ increase in remittances amounts to $\$ 8$ (Mexican pesos) for the households with access to EMI and $\$ 59.8$ for households without access to EMI. The elasticity of HHE with respect to remittances is given in row 5 . Row 6 shows the increase in HHE due specifically 
to increase in remittances: $\$ 0.02$ out of $\$ 8$ for households with access to EMI and $\$ 3.49$ out of $\$ 59.8$ for households without access to EMI, which indicate increases of $0.25 \%$ and $5.836 \%$ respectively, as shown in row 10 . Row 7 presents the estimated elasticity of HHE with respect to total expenditure, and row 8 the increase in HHE due to increase in household expenditures. The increase of $\$ 0.431$ for households with access to EMI and $\$ 4.300$ for households without access represent increases of $5.383 \%$ and $7.190 \%$ respectively, as shown in row 11 . Adding both effects, the remittance and expenditure effects, the total increase in HHE is $\$ 0.451$ for households with access to EMI and of $\$ 7.789$ for households without access, representing increases of $5.633 \%$ and $13.026 \%$ respectively. If the money fungibility hypothesis held, we would expect the remittance effect to have been zero.

Note that these results represent the social value of remittances because they include values for $w^{*}<0$ that are generated in our model by households with lower expenditures per capita. Note that differences in the results arise from the distinction between households with/without access to EMI and not from the particular measurement method used. Only in the case of GLS using all observations ( $w \geq 0$ ), a regression suggested by Deaton (1997), we obtain lower coefficients because many zeroes are included.

Rows 14 through 20 of Table 5 follow the same order as rows 6 to 12 and they measure the marginal effects or private values in this case, as they only consider the cases for $\mathrm{w}>0$. We find that an increase of $10 \%$ in remittances increases HHE by $3.799 \%$ for people with access to EMI and by $9.457 \%$ (row 20) for households without access. The total $9.457 \%$ is divided in $4.378 \%$ due to "earmarked" remittances and $5.079 \%$ due to the increase in expenditure. In other words, the availability of an extra peso will generate an increase of $5.079 \%$ in HHE, but if that peso comes from remittances it will generate an additional increase of $4.378 \%$ in HHE. In general, the results of the marginal effects range from $8.7 \%$ to $9.9 \%$ for households without access to EMI and from 3.4 to $3.8 \%$ for households with access. These results measure the private value of remittances.

Our results show that even when the elasticity of health expenditures with respect to total expenditures is greater than one, the effect of remittance transfers generate an even greater effect on health expenditure for households without access to EMI. Given the importance of health expenditure on social welfare and on the formation of human capital, there should be a public policy aimed at reducing the cost of receiving remittances, especially in the regions with high poverty. Such a policy will indirectly promote health expenditure among those without access to EMI, leading to a society with better health. 
Table 5

Interpretation of Results: An Example

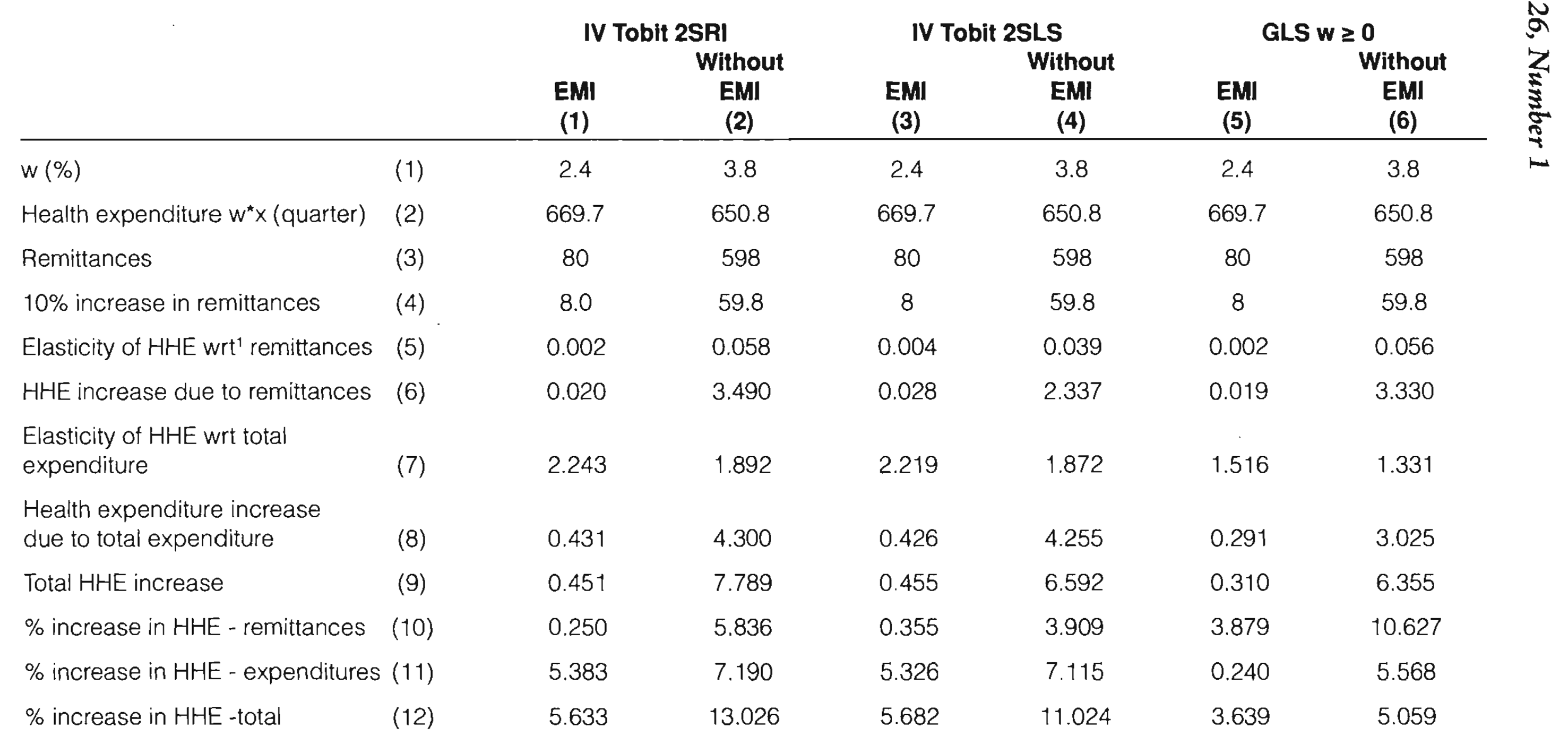


Table 5 cont'd

\section{Interpretation of Results: An Example}

\section{Marginal effects}

Elasticity of HHE wrt remittances (13)

0.003

0.044

0.003

GLS w $>0$

$\mathrm{HHE}$ increase due to remittances

0.022

2.618

0.025

0.036

0.002

0.055

Elasticity of HHE wrt total

expenditure

1.469

1.337

1.460

1.329

1.344

1.173

Health expenditure increase

due to total expenditure

0.282

3.037

0.280

3.020

0.258

2.665

Total HHE increase

0.304

5.655

0.305

5.202

0.277

5.929

$\%$ increase in $\mathrm{HHE}$ - remittances

0.273

4.378

0.313

3.649

0.237

5.458

$\%$ increase in HHE - expenditures

3.526

5.079

3.504

5.050

3.226

4.457

$\%$ increase in HHE -total

(20)

3.799

9.457

3.816

8.699

3.462

9.915

${ }^{1} \mathrm{HHE}$ wrt: household's health expenditures with respect to. 


\section{Conclusion}

This paper examines the relationship between remittances and the households' expenditure on health, using data from Mexico for the year 2004. We study this relationship by controlling for the household's total monetary expenditure, migration, composition and size of the family, marital status and sex of the head of the household, and region and size of the locality. The most important control variable is the one related to household's expenditure that measures availability of resources. As remittances are a part of total household expenditure, a positive relationship with the proportion of the household's expenditure on health would indicate that the proportion devoted to expenditure on health is increasing with remittances. Therefore, we can conclude that health expenditure is a target of remittances and we can reject the hypothesis that money is fungible, since even when a dollar is a dollar, a dollar from remittances is being devoted in part to health expenditures. This result is true for households without access to employment's medical insurance, that is, for households in the agricultural and in the informal sectors of the Mexican economy, which are the sectors with a high prevalence of poverty. This result suggests there are welfare benefits from implementing a strategy which would reduce the cost of receiving remittances in poor regions.

In order to compare the effects of institutional transfers with the effects of remittances, we also study the relationship between institutional transfers to the households and the proportion of expenditure on health, but we do not find a statistically significant relationship. The positive relationship between remittances and the proportion of the household's health expenditures together with the lack of a similar relationship for institutional transfers suggest that it is mainly remittances, and not institutional transfers, that contribute to a household's share of expenditure on health. These suggest that while money is not fungible in the case of remittances, the same cannot be said about money from institutional transfers. The results are robust to changing the definition of access to employment's medical insurance.

\section{Notes}

1. See Condouel et al. (2002) and Deaton (1997).

2. McKenzie (2007) argues that we must find a variable related to the migration of a member of the household and one that explains why a household with a migrant household member receives more remittances than another similar household. We look for answers to these questions considering the probability of the household receiving remittances and the probability of migrating. 
3. Usually when the father or mother of a family have EMI in their job, their children also have access to it. But even if the head of the family or the spouse have access to EMI, this does not imply that other members would also have access. Therefore, this measure is only an approximation, but even with this broad definition we find differences in the means and in the estimated parameters of the two groups.

4. See Robilliard and Robinson (1999) for a discussion of the differences between household surveys and national accounts data and a methodology to reconcile them.

5. The ENIGH has information about 32 Federal States, 503 localities, 4 strata (size of the locality) and 1,687 expansion factors that could be repeated in different States, localities or strata. This information allows us to distinguish 3,074 clusters or ultimate sampling units which for 22,595 observed households gives us an average of 7.4 households by cluster.

6. This function appears in Deaton (1997, pp. 268-69) and is derived from a cost function, $c(u, p, n)=n^{\theta} \alpha(p) u^{\beta(p)}$ where $u$ is the utility function, $\theta$ is a parameter to control for scale economies in the household, $\alpha(p)$ is linearly homogeneous and $\beta(p)$ is homogeneous of degree zero in prices. Considering that $\partial \operatorname{lnc} / \partial p_{i}=w_{i}$ and taking $\ln \alpha(p)=\Sigma \alpha_{k} \ln p_{k}$ and $\ln \beta(p)=\Sigma \beta_{k} \ln p_{k}$ the system of demands will take the form of a Working equation $\mathrm{w}_{\mathrm{i}}=\alpha_{\mathrm{i}}^{*}+\beta_{\mathrm{i}} \ln \left(\mathrm{x} / \mathrm{n}^{\theta}\right)=\alpha_{\mathrm{i}}{ }^{*}+\beta_{\mathrm{i}} \ln (\mathrm{x} / \mathrm{n})+\beta_{\mathrm{i}}(1-\theta) \ln n$, which is the equation that is being used here.

7. The $u_{c}$ is the deviation from the average $w$ at the locality $c$. It is assumed that these deviations are normal with mean zero and constant variance in the random effects (RE) model. We use the STATA's program instructions xttobit for the Tobit model and xtreg for the GLS model with quadrature equal to 12 to do our estimations.

8. We calculate distances to the border of 79 localities. When we do not know the distance from the locality to the border we use the distance between the state's capital and the U.S. border.

9. The derivability of equation (1) from a cost function allows us to interpret the marginal effects as the distance to a threshold or as originated in a utility function. This distance to the threshold $\mathrm{w}_{\mathrm{ch}}{ }^{*}=0$ measures the amount the household is to give in order to obtain other goods.

10. We also try to manage the problem of censored data as a case of self selection in an equation for remittances, but the obtained inverse mills-ratio or Heckman's 
lambda is not significantly different from zero. This implies that it is not convenient to use the self selection methodology to obtain corrected estimates.

11. The additional variable included in the 2SRI procedure was not significantly different from zero, but the theoretical reason to use instrumental variables still persists: health expenditure could be generating remittances. The additional variable, obtained in the first step of the procedure, looses significance when the control variable for migration enters into the model indicating the possibility that both variables are collinear.

12. We control for the problem of heterogeneity through the inclusion of different kinds of variations, such as the composition of the family, total expenditure, scale effects, migration, and so on. With regards to the adequacy of using the Tobit model, Johnston and DiNardo (1997) suggest comparing the relationship $\beta / \sigma$ for the probit and Tobit models. We find that with the exception of two variables the IV Tobit 2SRI and the probit models maintain the same signs, but when comparing the IV Tobit 2SLS with its respective probit model the remittances variable changes sign. Therefore, we feel confident that the 2SRI model is well specified as a Tobit model. To save space, we do not report the results. Interested readers may obtain the results from the author.

13. The effects on means are estimated through equation (1). For example, for remittances we will have: $\partial w / \partial r e m=\eta_{1}+2 \eta_{2}$ rem $+\eta_{5} E M I$. The elasticities of health expenditure with respect to total monetary expenditures (constant size of the household) and with respect to remittances, $e_{x}$ and $e_{R}$, are defined as:

$e_{\mathrm{x}}=\frac{\partial \ln q}{\ln x}=\frac{\frac{\partial w}{\partial \ln (x / n)}}{w}+1 ; \quad e_{\mathrm{R}}=\frac{\partial \ln q}{\partial \ln r e m}=\frac{r e m}{w} \cdot \frac{\partial w}{\partial r e m}+\frac{r e m}{x}$

where the term rem/x is the expenditure effect because it assumes $\partial x / \partial r e m=1$.

\section{References}

Acosta, P., Fajnzylber, P., \& Lopez, J. H. (2007). The impact of remittances on poverty and human capital: Evidence from Latin American household surveys. World Bank, Policy Research Working Paper WPS 4247.

Aíres, B. (2005). Transforming labor markets and promoting financial democracy. Inter-American Development Bank, Remittances 2005. 
Amuedo-Dorantes, C., \& Pozo, S. (2008). New evidence on the role of remittances on healthcare expenditures by Mexican households. Working paper.

Amuedo-Dorantes, C., Sainz, T., \& Pozo, S. (2007). Remittances and healthcare expenditure patterns of populations in origin communities: Evidence from Mexico. INTAL - ITD, Working Paper 25.

Atkinson, A. B., Gomulka, J., \& Stern, N. H. (1990). Spending on alcohol: Evidence from the family expenditure survey 1970-1983. Economic Journal, 100(402), 808-827.

Banerjee, A. V., \& Duflo, E. (2007). The economic lives of the poor. Journal of Economic Perspectives, 21(1), 141-167.

BANXICO (Banco de México). (2005). Balanza de pagos. Remesas familiares. Retrieved from www.banxico.gob.mx/eInfoFinanciera/FSinfoFinanciera.html.

BANXICO (Banco de México). (2008). Balanza de pagos. Ingresos por remesas familiares. Distribución por Entidad Federativa: Banco de México.

Cameron, A. C., \& Trivedi, P. K. (2005). Microeconometrics: Methods and applications (1 st ed.). New York: Cambridge University Press.

Cardona, L., \& Medina, C. (2005). Migration as a safety net and effects of remittances on household consumption: The case of Colombia. Banco de la República, Economic Research Unit.

Coudouel, A., Hentsche1, J. S., \& Wodon, Q. T. (2002). Poverty measurement and analysis. In J. Klugman (Ed.), A Sourcebook for Poverty Reduction Strategies (Vol. 1, p. 1260): World Bank.

Deaton, A. (1989). Looking for boy-girl discrimination in household expenditure data. The World Bank Economic Review, 3(1), 1-15.

Deaton, A. (1997). The analysis of household surveys: A microeconometric approach to development policy. World Bank: Washington, DC. The John Hopkins University Press.

Debb, P., \& Trivedi, P. K. (2002). The structure of demand for health care: Latent class versus two-part models. Journal of Health Economics, 21(4), 601-625.

Gibson, J., \& Rozelle, S. D. (2004). Is it better to be a boy? A disaggregated outlay equivalent analysis of gender bias in Papua New Guinea. Journal of Development Studies, 40(3), 115-136.

Hausman, J. A. (1978). Specification tests in econometrics. Econometrica, 46(6), 1251-1271.

Hildebrandt, N., \& McKenzie, D. J. (2005). The effects of migration on child health in Mexico. World Bank, Policy Research Working Paper WPS 3573. 
Hong, G. S., \& Kim, S. Y. (2000). Out-of-pocket health care expenditure patterns and financial burden across the life cycle stages. Journal of Consumer Affairs, $34(2), 291-313$.

Johnston, J., \& DiNardo, J. (1997). Econometric methods. New York: McGraw-Hill, Higher Education.

López-Córdova, E. (2006). Globalization, migration and development: The role of Mexican migrant remittances. Inter-American Development Bank.

McKenzie, D. J. (2007). Beyond remittances: The effects of migration on Mexican households. In C. Ozden \& M. Schiff (Eds.), International Migration, Remittances \& the Brain Drain. World Bank.

McKenzie, D. J., \& Sasin, M. J. (2007). Migration, remittances, poverty, and human capital: Conceptual and empirical challenges. World Bank.

Ochoa-Díaz, H., Héctor, S. P., Ruíz-Flores, M., \& Fuller, M. (1999). Social inequalities and health in rural Chiapas, Mexico: Agricultural economy, nutrition, and child health in La Fraylesca region. Cad. Saúde Pública, 15(2), 261-270.

Robilliard, A. S., \& Robinson, S. (2001). Reconciling household surveys and national accounts data using a cross entropy estimation method. International Food Policy Research Institute.

Rubalcava, L., Teruel, G., Thomas, D., \& Goldman, N. (2008). The healthy migrant effect: New findings from the Mexican Family Life Survey. American Journal of Public Health, 98(1), 78-84.

Smith, R. J., \& Blundell, R. W. (1986). An exogeneity test for a simultaneous equation Tobit Model with an application to labor supply. Econometrica, 54(3), 679685 .

Suárez-Berenguela, R. (2000). Health system inequalities and inequities in Latin America and the Caribbean: Findings and policy implications. World Bank, working paper prepared for the Health and Human Development Division of the Pan American Health Organization - World Health Organization.

Terza, J. V., Basu, A., \& Rathouz, P. J. (2008). Two-stage residual inclusion estimation: Addressing endogeneity in health econometric modeling. Journal of Health Economics.

Tuirán, R., Fuentes, C., \& Avila, J. L. (2002). Indice de intensidad migratoria México-Estados Unidos. Mexico: Consejo Nacional de Poblacion.

Valero-Gil, J. (2006). Estimación de elasticidades e impuestos óptimos a los bienes más consumidos en México. Estudios Económicos, 21(2), 121-176.

Wagstaff, A. (2002). Poverty and health sector inequalities. Bull World Health Organ, 80(2), 97-105. 
Working, H. (1943). Statistical laws of family expenditure. Journal of the American Statistical Association, 38(221), 43-56.

World Health Organization. (2007a). National health accounts. Retrieved from www.who.int/entity/nha/country/MEX.xls.

World Health Organization. (2007b). The world health report. Retrieved from www. who.int/whr/en/.

\section{Biographical Sketch of the Author}

Jorge N. Valero-Gil is a professor of Economics at Universidad Autónoma de Nuevo Leon, Monterrey, Mexico. He received his Ph.D. in Economics from the University of California at Santa Barbara in 1989. His current research focuses on household expenditures, informality, poverty, and on the influence that the legal system has on the formation of an informal sector in the Mexican economy. His email address is jvalero@faeco.uanl.mx. 